\title{
Among Uncertainty, Fear and Reluctance to Change: The Basis of the 'Rejection' to the New Constitution in Chile's Big Business Before the Social Outbreak of 2019
}

\author{
Nelson Alejandro Osorio Rauld \\ University of Alicante \\ Venus Reyes Palacios \\ University of Santiago
}

\begin{abstract}
The institutional response to the social outbreak of 18/O in Chile was the National Referendum for a new Constitution, which had an overwhelming result in favor of approving the constitutional change. However, within the minority group that voted against the change, there is part of the large Chilean business community. This article seeks to show the foundations of the main business leaders of two employers' organizations in Chile: the National Society of Agriculture and the Sociedad de Fomento Fabril, who rejected the idea of a new Constitution years before the social outbreak, as a result of the Constitutional Process promoted between 2015 and 2016 by the government of former President Michelle Bachelet. From 40 interviews with members of the business elite, it is concluded that uncertainty, fear and aversion support this conservative stance with a complex base, marked by its institutional trust and fear of the creation of a new political order. The analysis is interesting, because possibly the magnitude of the social outbreak and its consequences, managed to change the public positioning of some business leaders.
\end{abstract}

Keywords: big business, new constitution, rejection, Chile, constitutional change

\section{INTRODUCTION}

On October 18, 2019, Chile was the scene of a large-scale social outbreak, in which different sectors of society took to the streets to protest against a set of negative situations that had been accumulating a deep uneasiness in the country since the return to democracy. This event was not local but rather national in character, and the protest quickly spread throughout the national territory, leading the government of President Sebastián Piñera to call out the Armed Forces to stop the social uprising, with serious violations of the human rights of the demonstrators, something that had not happened in Chile since the military dictatorship (Avendaño \& Osorio, 2021).

The demonstrations after the outbreak continued with intensity and systematicity, gathering millions of people in different cities to request structural changes in the country. In response to social demands, party leaders of different political parties drafted the "Acuerdo por la Paz Social y Nueva Constitución" (Agreement for Social Peace and the New Constitution), which involved holding a referendum to democratically decide on a new Constitution. Thus, almost a year later, on October 25, 2020, almost $80 \%$ 
of the citizens decided to replace the current Fundamental Charter through a Constitutional Convention composed of citizens without the presence of professional politicians (Servel, 2020).

The result of the referendum to change the Constitution allowed the consolidation of a majority desire of the citizens that had been registered since 2011 (PNUD, 2015a; Desoc-Coes, 2019; Criteria, 2020; Barómetro del trabajo, 2020). Indeed, as the PNUD report on "Los tiempos de la politización" (2015b) has shown, it is from that date onwards that an accelerated conflict and protest process began to develop in Chile in order to change the institutional rules in force in the country.

However, despite the 'overwhelming' result of the referendum, not all social sectors seemed to be persuaded of the desire to change the Fundamental Text, since just over $20 \%$ decided to defend at the polls the institutionalism inherited from the dictatorship, opting for the permanence of the current Constitution. This small minority sector of the country is mainly composed of people identified with the political sector of the right, and many of them belong to the wealthy social strata of the country; proof of this was the places where the 'Rejection' option in favor of changing the Constitution won, neighborhoods where people with higher levels of income and education live ${ }^{1}$.

Within this $21.72 \%$ that opted for 'Reject' is a large portion of the large Chilean business community, which has historically supported the political right (Avendaño \& Escudero, 2016; Arriagada, 2004) and has persistently defended Pinochet's economic legacy (Osorio, 2019a and 2019c). In the context of the military dictatorship they supported the emerging Constitution (Campero, 1984), a regulation that recognized an 'imperfect' democracy that was publicly defended by businessmen from 1990 to 2019, despite the fact that this institutional design negatively conditioned the evolution of the political process (Garretón, 2015; Huneeus, 2014), with great responsibility in the social uprising of the 18/O of 2019.

Chilean businessmen have always been conservative about this institutional framework, especially when it came to changing the Constitution. Economic reasons were publicly adduced to support their position. In the context of the Constitutional Process promoted in 2015 by former President Michelle Bachelet, Hermann Von Mühlenbrock, former president of SOFOFA, an important employer organization, stated that "It would not be appropriate to talk about a new Constitution (...) because it is not possible to create more uncertainty" (La Tercera, April 29, 2015a); or as the principal millionaire of Chile, Andrónico Luksic, also stated publicly, "In addition to the low price of copper, the consequent exchange depreciation and the economic slowdown, a series of reforms that generate uncertainty and distrust have been added" (Emol, April 15, 2016).

Despite the presence of big business in the media in favor of Pinochet's Constitution, the truth is that we know little or nothing about the rationale that the business elite had at the individual level for rejecting a new Constitution until shortly before the social outbreak of 2019.

Regarding the latter, it is surprising how little interest the social sciences have shown in terms of understanding and analyzing the "political ways of thinking, feeling or acting" of those who direct economic activity, particularly given the importance currently given by leading intellectuals to the political culture of the elites in understanding the life of countries (Acemoglu \& Robinson, 2012; Putnam, 1973). Thus, in a different direction, the study of Chilean businessmen has focused on other research areas, such as the concentration of economic power and the changes that this phenomenon has produced in the social composition of this group and of the companies (Lagos, 1960; Dahse, 1979; Rozas \& Marín, 1989; Fazio, 2005; Montero, 1997). Nowadays, sociology has begun to give more attention to the sociocultural characteristics of the economic elite, seeking to understand their networks and connections (Cárdenas, 2016), as well as the mobilization of cultural resources in order to influence the public sphere (Undurraga, 2013). Despite these contributions, there is still a lack of academic production referring to the subjective dimension of the politics of those who form an essential part of this social actor, which reveals a promising but scarcely explored research field.

In view of the above, based on the analysis of 40 interviews with business leaders from the Chile's Sociedad de Fomento Fabril (SOFOFA, Manufacturers' Association) and the Sociedad Nacional de Agricultura (SNA, National Society of Agriculture), this article sought to show the main reasons or justifications that Chilean top representatives of the business community had for not changing the Constitution until shortly before the social outbreak of 2019, in order to contribute to fill the gap described 
above. The proposed analysis is interesting because possibly the social outbreak scale and the democratic events that followed, managed to change the public positioning of some business leaders. This was stated shortly after the Agreement for Social Peace and the New Constitution, by the former president of SOFOFA, Bernardo Larraín Matte, who was in favor of the Approval option, "Initially I am in favor of the Approval of the new Constitution [...] I do not agree with the rejection that says that the current Constitution does not require any modification. It seems to me that it is immobility that will lead us to deepen the crisis" (La Tercera, January 01, 2020). This kind of public statements outside the traditional 'economicism' attributed to businessmen, offers some light regarding the importance of knowing at an individual level the grounds for rejecting a constitutional change at a moment prior to a social outbreak; always under the theoretical assumption that the members of the elites possess complex thoughts that are not reduced only to the logic of cost and benefit.

Next, the research design applied in this work is developed and then the results obtained are described. The topics analyzed were the foundations of the elite's positions regarding the constitutional process promoted by Michelle Bachelet's government between 2015 and 2016; regarding the possibility of changing the Constitution in the near future; and finally, the interviewees' evaluations of the constitutional change mechanism (Constituent Assembly, Congress, experts, etc.).

\section{RESEARCH DESIGN}

\section{Information Production}

For the study of the business elite, between mid-2018 and 2019, 40 semi-structured interviews were conducted with presidents and vice presidents of SNA and SOFOFA, who hold positions of leadership and representation, and were democratically elected by the business community itself, so they have legitimacy before their peers. These business associations are the oldest in the country, have always been influential in the public sphere and, in addition, due to their elite status, have an enormous capacity to mobilize resources as an "interest group" and "lobby" (Osorio \& Reig, 2020). The SNA has historically been linked to conservative positions, defending values such as private property, with a marked political affinity to the right (Correa, 2005). The expropriation policies implemented in the framework of the Agrarian Reform between 1960 and 1970 affected them significantly, both in terms of land ownership and the political violence that this process brought about. By far, SOFOFA's industrial entrepreneurship has been more inclined towards modernisation and more liberal economic and political values, and linked to centrist parties with a developmentalist orientation (Arriagada, 2004). However, it was not until the "socialist experience" and the dictatorship that the ideological affinities of the employers' organisations under study became more homogenised and radicalised towards the right (Avendaño and Escudero, 2016, pp. 53-54).

Three techniques were used to coordinate the interviews: 1) Formal channels, inviting the leaders to participate in the study by means of a letter, which was by far the most effective way (Thomas, 1995); 2) "snowball", in which the interviewee was asked to link up with another participant (Salamanca \& MartínCrespo, 2007) and; 3) support from contacts close to the elite (Atria et al., 2017). This last technique was used exclusively when the previous ones were not successful.

\section{Information Analysis}

Following the recommendations of the literature about elites that suggests the use of an interpretative strategy to analyze the 'verbal expressions' of select minorities (because of their high cultural capital) (Bourdieu, 2012; Putnam, 1973; Morán, 1995), this article employed the technique of Content Analysis to analyze the utterances of the subjects under investigation. The Content Analysis allows to objectively know the authors' positions, seeking to identify their feelings, intentions, values and/or attitudes (Krippendorff, 1990). In addition, it is a resource that takes into consideration the context in which the communication was produced, being able to situate the verbal expressions of the authors of the statements (Navarro \& Díaz, 1994). This allows the elaboration of inferences, understood as a "logical operation by which a proposition is admitted by virtue of its relation with other propositions already admitted as true" (Bardin, 1986, p. 29).

Journal of Applied Business and Economics Vol. 23(6) 2021 
The interviews were transcribed and entered into the ATLAS.ti software, for which a coding framework was used to generate more than 250 recording units. Subsequently, the information was analyzed and then interpreted.

\section{RESULTS}

\section{Constituent Process in Michelle Bachelet's Government \\ Fraud/Populism/Rejection}

As mentioned in previous pages, an intense process of social conflict and demonstrations began to develop in Chile in 2011. Thousands of demonstrations and social protests called for a change towards a new development model -to reduce the high levels of inequality- and also for greater citizen participation in the most important decisions. The demonstrations were focused in Santiago and also in other regions in the north and south of the country. The most lasting and powerful movement was the student one (Rojas, 2012), which pressured the government of Sebastián Piñera (2010-2014) for more than a year to change from a privatized education to one understood as a social right. In fact, the political impact on this government was significant, as it had to make cabinet changes and replace three ministers of education. In August 2011, President Piñera registered the highest level of disapproval of a government and a president since the return of democracy (Avendaño \& Osorio, 2016).

Although with lower intensity, the demonstrations for education continued until the end of the centerright coalition's government, whose demands were included in the proposals of the government program of the Nueva Mayoría (New Majority) -a center-left coalition that grouped the parties of the former Concertación together with the Communist Party (PC), which was presided over, for the second time, by President Michelle Bachelet (2014-2018). Thus, seeking to respond to the demands of the citizens and political actors who were pressing to change the institutional rules to make the changes requested by the citizenry, between 2015 and 2017, President Bachelet promoted the constituent process for a new Constitution. Its purpose was to encourage citizens to discuss values, rights and institutions that should be included in a future Fundamental Text, and it had several stages, ranging from individual participation to collective participation such as town meetings (Escudero, 2021). Citizen agreements and disagreements were reflected in the document "Las Bases Ciudadanas de la Nueva Constitución" (Citizen Bases of the New Constitution), delivered in October 2016 to the President for the drafting of the New Constitution Law Project.

The event was attended by 218,689 people and despite its non-binding nature, it was harshly criticized in the media by the employers' organizations at the time. In this regard, different business associations expressed their opinion, arguing that its implementation would have a negative impact on investment. For example, the president of the Confederación de la Producción y del Comercio (Confederation of Production and Commerce, CPC), Alberto Salas, stated: "Adding now the considerable uncertainty of a constitutional reform causes great concern among economic actors, which could further affect investment, by paralyzing or delaying the completion of projects, due to the lack of certainty that opens up in several areas with an announcement like this" (La Tercera, April 29, 2015b). Something not very different from what was stated by Ricardo Mewes, president of the Cámara Nacional de Comercio (National Chamber of Commerce, $\mathrm{CNC}$ ), who admitted that "as a guild, we are concerned about the initiation of a constituent process, at a time when the country requires institutional stability; an initiative of this type will only create greater uncertainty and will do nothing to restore confidence and revitalize our economy" (La Tercera, April 30, 2015). In the same direction, the former president of the Sociedad Nacional de Agricultura (National Agriculture Society, SNA by its Spanish acronym), Patricio Crespo, argued that the process "leaves the country exposed for some three or four more years to this uncertainty, to these contrived but instrumental managements" (La Tercera, October 14, 2015).

A few months before the social outbreak of $18 / \mathrm{O}$, the research conducted showed that the business leaders interviewed continued to have a critical assessment very similar to that publicly displayed at the time of implementation of the constituent process (2015-2017). In them, the business elite continued to 
reject across the board a participatory process to change the Constitution. This is how one of the participants refers to this event:

"A disaster, a mockery! I feel bad for the people who honestly tried to participate and expose their ideas, a mockery! and a pointless waste of money" (Elite member 16).

One of the theoretical foundations that justify this position of "Rejection" for the business elite has to do with the perception of a process considered by its members as a "fraud", carried out by the Bachelet government for electoral purposes. In this case, what was sought was to use the constituent process instrumentally to generate expectations among citizens, seeking the reelection of the coalition. This perception of generalized political deception among the interviewees, of course, is similar to what some leaders expressed publicly at the time, as pointed out by the president of the SNA, who was under pressure due to the coincidence between the dates of the constituent process and the upcoming municipal, parliamentary and presidential elections. In his opinion this "speaks that behind this there is an attempt to use this process, which is so delicate, for electoral interests" (La Tercera, October 14, 2015).

Another recurrent expression in the interviewees regarding the constituent process is the "populist" character attributed to the event, considered as an initiative that was carried out outside the institutional framework conferred by the 1980 Constitution itself. In this regard, several leaders highlighted the informal and demagogic nature of the process:

"Terrible, terrible! They were able to take the whole Chilean institutionality and all for a political idealism where minorities are once again making decisions for the whole country" (Elite member 5).

In any case, it is important to mention that the assessments of the members of the employers' associations are questionable, since the constituent process was not 'extra-institutional' in nature. In fact, as mentioned above, its nature was more of a consultative nature, so in order it would have had an institutional impact it should have exceeded the quorums for constitutional reform (2/3), which was precisely what did not happen. In fact, once President Sebastián Piñera took office in March 2018, he immediately removed the project for a new Constitution, thus temporarily closing the chapter on a new Fundamental Charter.

\section{Constitutional Reforms and/or the Change of the Constitution}

As is well known, in 2005, Chile underwent constitutional reforms that allowed the Armed Forces to be subordinated to civilian power, which was a milestone of great significance for Chilean democracy (Garretón, 2015; Huneeus, 2014). Despite their enactment, the reforms did not eliminate all the "authoritarian enclaves", so the Concertación de Partidos por la Democracia (Coalition of Parties for Democracy) put the need for new changes to the Fundamental Text back on the public agenda. This will open a shy debate, the first signs of which can be seen in the electoral speeches of the presidential candidates in 2009 (Fuentes, 2012). But in fact, the constitutional change began to acquire relevance in public opinion in the first government of President Sebastián Piñera (2010-2014), after months of demonstrations that, as already indicated, showed the limits of Chilean institutionality (Osorio, 2019b and 2019c). As can be seen in Figure 1, this triggered citizen support for profound changes in institutional rules.

Thus, the constitutional discussion is opened in the public opinion, on which two positions can be distinguished: those who seek a new Fundamental Charter or deep changes to it, and, from the other side of the road, those who reject a new Constitution, but who are open to partial reforms as long as the quorums for constitutional reform are exceeded. 


\section{FIGURE 1 \\ HOW MUCH DO YOU AGREE WITH SEEKING TO CARRY OUT A CONSTITUTIONAL REFORM?}

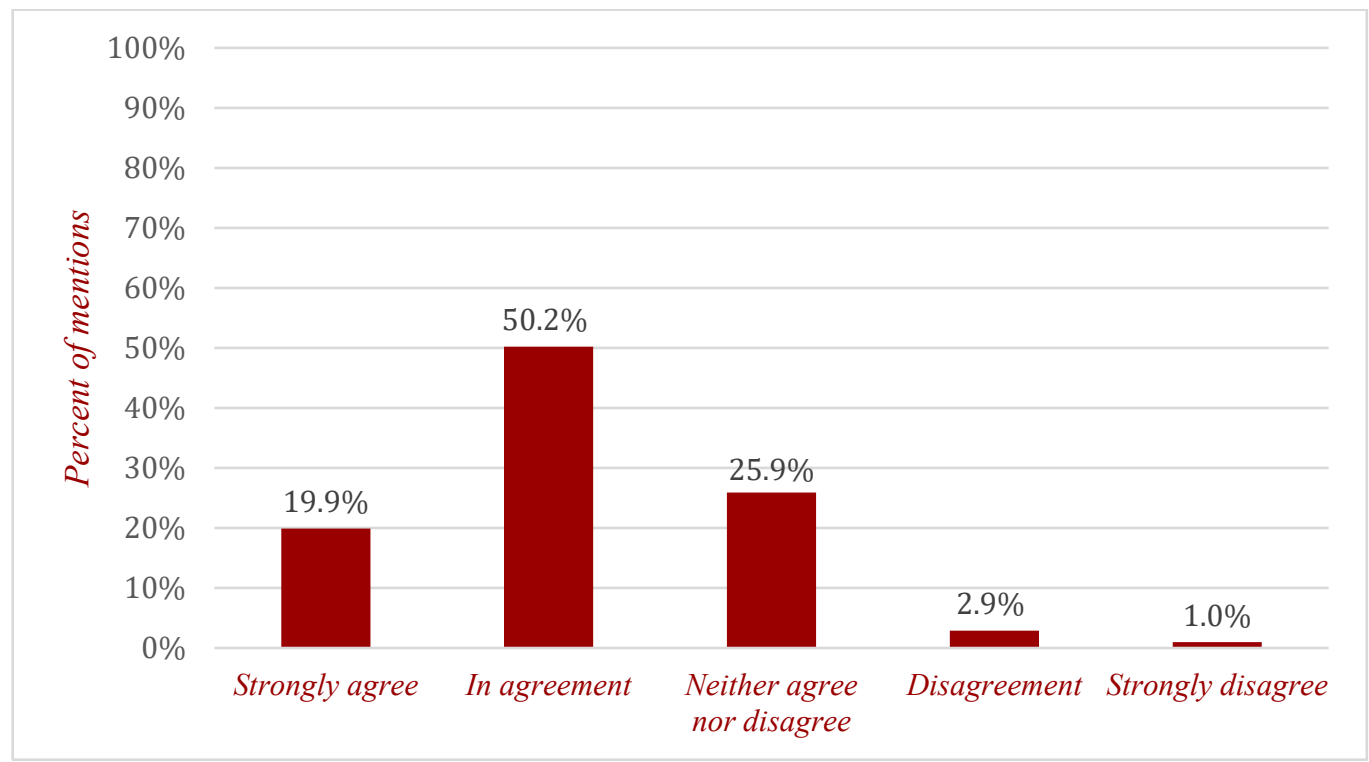

Source: PNUD (2015a)

Of course, those who are in favor of a profound change argue, among other reasons, that the current Constitution lacks legitimacy in its origin, which does not generate "constitutional patriotism" in the population (Fuentes \& Joignant, 2015). Furthermore, despite the changes implemented in democracy, it is argued that it continues to have "majority neutralizing" devices, which would distort the political process by imposing the "Democracia protegida" (protected democracy) project with rules that would seek its permanence (Atria, 2014). It also criticizes the model of socioeconomic development promoted by the Constitution, based on the "principle of subsidiarity", which restricts the powers of the State, especially in terms of intervention and regulation; a limitation on State action that, in short, places the market as the main allocator of resources (García García, 2014), which has a negative impact on the public sphere.

"Under the 1980 Constitution, the State's role is defined as subsidiary and the exercise of freedom and the consequent entrepreneurship of the people is defined as the axis of development. The State ceases to assume a paternalistic role and hands over the responsibility of providing for the satisfaction of needs to the people themselves and their capacity for effort, work and self-improvement (...) Now people have progressively understood and assumed that the satisfaction of health, education, work, social security, economic development, etc., are matters that depend primarily on themselves and that the State will no longer always be there to provide for them" (van de Wyngard, 2013, p. 281).

In addition, those who defend the 1980 Constitution do so in recognition of its contribution to the country's economic growth with democratic stability, leading Chile to become a leader in the region (Cordero, 2015; van de Wyngard, 2013; Rojas, 2013). Furthermore, the belief that the Constitution would prevent the revival of the political order that developed from the 1925 Constitution, which ended up opening the door to a Marxist president with the capacity to expropriate private property, as happened dramatically for the elite during the Unidad Popular (1970-1973) (Popular Unity government). To avoid this situation, the Constitution would have "counter-majoritarian" devices that would protect the fundamental rights of Chileans, such as freedom and private property (Cordero, 2015). 


\section{Rejection/Reform}

Despite the fact that shortly before the social outbreak the majority of Chileans were in favor of drafting a new Constitution, the business elite in this same scenario did not show any kind of division, and remained extraordinarily aligned around the "Rejection" position, unaware, of course, that this position would be expressed a year later at the ballot box for the 2020 referendum. However, this 'conservative' stance, according to the evidence found, did not imply immobility or blockage for the business community, since it was also possible to identify in the interviewees a certain openness to the introduction of relevant changes, which could even be profound and coincide with progressive discourses, for example, in matters related to decentralization or the elimination of the military from political decision making.

"There are Constitutions in the world that have never been changed. I believe that ours has undergone changes with more improvements than decreases. We should improve what needs to be improved, without any doubt, and in fact the Constitution has had changes: the appointed senators, do we all agree that the appointed senators should be out of office? Well, that was done, there are mechanisms for that" (Elite member 3).

However, the 'reformist' attitude of the business elite was completely different regarding their position in the face of a fictitious scenario of a change in the Constitution before the social outbreak, since in the face of this possibility, the interviewees expressed a conservative position and aversion to changes that could modify the contents of the current Constitution; contents that for this minority are essential, such as fundamental rights, which are protected through the "principle of subsidiarity", which gives greater prevalence to economic freedoms than to the 'general interest' (Atria, 2014). This was expressed by this interviewee, whose speech is representative of the feelings of those who held positions of union representation at the time prior to the outbreak.

"I believe that a constitutional change has to be made to the extent that countries need to modernize and that the Constitution allows them to make those changes, but as long as the right to life, the right to property, the right to grow, to defense are respected, I believe that the Constitution is adequate" (Elite member 30).

In a discursive similarity with the intellectual world that defended Pinochet's Constitution, the business community also valued positively the economic growth and political stability that Chile had achieved from 1990 to 2019 (CEP, 2017; Cordero, 2015; van de Wyngard, 2013). From this perspective, the interviewees maintained that as long as progress continued to be made, the objective indicators regarding life quality would continue to improve. What is analytically interesting is that, in accordance with the testimonies collected in this work, for the individuals examined this relationship among "Constitution", "economic growth" and "governance" was effectively supported by the "constitutional bases" of the current Fundamental Text, since for them it makes individual freedoms and the market prevail over the State. This is always to the extent that private property, which for business leaders is considered the "engine" or "driver" of society, is protected. Its replacement by another Constitution would open a scenario of uncertainty that, as an economic elite, they were not willing to risk.

"Chile is moving forward, Chile has an order, it has a way of doing things. Of course there is room for improvement, but not everything is bad, that is the difference I see. I feel that there are basic things that if you change them, it implies a fundamental change, and among them is the right to property as key, it is the axis, then, without a doubt, there are things in the Constitution that are fundamental and if you change them, you change the country from the beginning" (Elite member 19).

"I think that the right to property should be a strong, solid right, because what happens is that I think that society evolves because of individual appetites" (Elite member 3). 
The solid belief in the Constitution among the interviewed elite also entailed at that time another element of support discovered by the interviews: the aversion to radical changes that could imply the elaboration of a new Constitution. Thus, the mere possibility of a change in the institutional rules generated very negative reactions among the elite, especially because they brought back to the present the 'historical' and 'collective' memory of the government of president Allende, "If people talk to me about changing the Constitution, I would be scared to death because history tells me so, and I tell you the truth, I am terrified..." (Elite member 10).

By virtue of the above, it is possible to identify the negative impact of the memory linked to the expropriation experience of the agrarian reform during Salvador Allende's government, which confirms the validity of the historical and collective memory in this social group as it occurs with the rest of Chilean society (Osorio, 2019a). This can be verified by an interviewee who mentions that a new Constitution could affect the "water rights" that today mostly benefit the private sector (Larraín, 2006). According to the interviewee, this would affect their investments by making water a "public good", which would be similar to the scenario experienced during the government of President Allende:

"(...) the person who is creating jobs and is doing things right, why are they going to remove his/her water service 30 years later, because someone decided? and we return to the agrarian reform of the Unidad Popular: the agrarian reform were badly exploited fields and who decided that? It was decided by a group, people who at one minute declared that they were doing it wrong, so it cannot be left to the discretion or subjectivity of just one person, of a group, wasn't everything that happened afterwards enough? (Elite member 6)".

\section{Axis Positions Before the Mechanism of Constitutional Change Fear/Intense Political Participation of Citizens}

The 'Rejection' positions towards the change of the Constitution entailed another aspect analyzed in this work: the political evaluations towards the change mechanism of the Constitution. In this regard, the literature on this issue identifies several mechanisms that can range from a Constituent Congress to participatory or hybrid formulas, such as the constituent assembly or the combination of political representatives with citizens (Negretto, 2015; Elster, 1995). In less participative versions, constitutions may be drafted by appointed councils, expert commissions or "firm organizations", the latter usually resulting from a sudden military intervention (Schmitt, 1996).

Regarding the constitutional change mechanism, empirical evidence in the Chilean case shows that the population is progressively opting for a popular approach (PNUD, 2015a; Desoc-Coes, 2019; Criteria, 2020; Barómetro del trabajo, 2020). This fact is not contingent, it has persisted over time and is related to the disaffection of citizens towards politics, political parties and Congress that has been registered in the last decades (Luna, 2016 and 2017). This separation between politics and society was already clearly expressed in 2013, for example, in the social preference for a constituent assembly $(44.7 \%$ of the surveyed population) (PNUD, 2015a). This preference increased over time as after the social outbreak and the "Agreement for Social Peace and the New Constitution", the percentage adhering to the exclusion of politicians in the drafting of the Constitution grew significantly (over 75\% in October 2019) (Desoc-Coes, 2019). Of course, all these analyses cleared up any possible doubt regarding the result of the 2020 referendum, in which $79 \%$ opted for a Constitutional Convention to draft the Constitution, against $21 \%$ who decided for a Joint Convention, composed of citizens and professional politicians.

Despite the evident impetus of the citizenry in favor of citizen participation in the drafting of an eventual Constitution, for the business community the option for a constituent assembly produced feelings of "fear" and "uncertainty", especially because of the possibility of affecting "fundamental rights". In this sense, judging by the words of the interviewees, this research could corroborate that for big business an exclusive citizen participation in the drafting of the Constitution is felt as a threat. This is mainly because, as has been shown in previous research, the favorite democracy model for those who manage economic activity is the "representative" one, since in it the political actors who perform it have characteristics of "responsibility" 
to legislate and watch over public affairs, characteristics that would not be enjoyed by the citizenry, which seems less qualified to exercise public functions of high importance in the future of the country.

"I prefer the democratic system we currently have where you elect people who make decisions, why? because not all people are well informed, so you delegate the responsibility to certain people, that seems sensible in the model of representative democracy" (Elite member 18).

This is how the interviewed business leaders manage to distinguish the importance of the mechanism in the content of a new Constitution, as if they were two things that cannot be separated. Therefore, mass participation is perceived as a negative threat to the established order, both in its economic and political aspects. Indeed, a Constitution drafted by the citizens was perceived at the time as a kind of "revenge" or "retaliation", especially because of the excessive concentration of wealth and inequality in the country. Of course, this would affect their social interests so their "Reject" option is evident, preferring instead moderate changes through Congress.

"For me the constituent assembly is an unmanageable institutionality that can result in anything. I believe in a demanding institutionality, of the executive power, of the legislative power, of the judicial power, and that they broaden the discussion as much as possible with the different actors" (Elite member 13).

"I think it depends on how it is managed. If it is managed in a technical way and by wise people, it would not be anti-private property. But a popular approach would be. Because Pinera can win the elections, he can have $55 \%$ of the votes, but if what is being voted is the right to property, that would be lost, because we are talking that there is economic concentration, so there are more those who do not have money than those who have money. It would be embodied in the Constitution if it is popularly generated" (Elite member 35).

The selected fragments are representative of the businessmen's feelings insofar as the great majority of the testimonies highlight the same problems addressed in this research. The above allows us to highlight the apprehension that was produced before the outbreak by a large citizen participation in the development of a Constitution, which is corroborated in the negative assessment of the constituent assembly as an "unmanageable institutionality", which contrasts with the representative balance provided by the National Congress.

Finally, it can be seen that the fears or threats detected by the analysis of the interviews allude to political power, but also to the dynamics of wealth accumulation in the country, in which the privileged position of the business sector would be at risk in the face of a possible intervention by those who "do not have". This fear that affected the interviewees finally became a reality in the election of constituents on May 15 and 16, 2021, since the results favored the political forces of the center-left and left, leaving the political sector of the right without any capacity to influence the direction of the new Constitution, confirming, in a way, the worst nightmares of those who direct and represent the economic activity in the country.

\section{CONCLUSIONS}

The contribution of the article was to show the basis of the position of "Rejection" to change the Constitution by the representatives of big business shortly before the social outbreak that led to a new political cycle, precisely, from a change of the current Constitution, which came from the Pinochet regime. The paper's main conclusion is that there is an extraordinary uniformity in the different dimensions that make up the positions of business leaders, which was reflected in the homogeneity of their verbal expressions, with very few nuances of difference between the accounts. 
The content analysis of the interviews showed a "conservative" position of the interviewees regarding events that have sought citizen participation in the elaboration of a new Constitution. This can be confirmed by the aversion of its affective component to the constituent process promoted by President Bachelet, as well as to the option of changing the Constitution in an eventual referendum. This aversion increases if the mission falls in the hands of the citizenry, but decreases if the task is assigned to the National Congress.

The research presented here shows that the interviewees' bases for justifying their conservative stance are related to their confidence in institutional rules, which prevent the creation of a political order such as the one that emerged with the 1925 Constitution. In this sense, for the elite under study, the current Constitution avoids returning to the days before the military coup of 1973, so that its evaluation shows with determination the weight of the historical and collective memory of the 'socialist experience' (1970-1973). To avoid recalling this memory that disrupts its political culture, the business community is in favor of progressive reforms that gradually modify the Constitution as long as they are made within the institutional framework conferred by the current text (exceeding the $2 / 3$ quorum for constitutional reform).

In addition, it can be inferred that the affection that the group feels for the Fundamental Law is also due to the model of socioeconomic development that it enshrines. This is why the "principle of subsidiarity" is so strongly defended, because it allows the private sector to prevail over the State by protecting private property over the "general interest" of society.

Finally, it is observed that for business representatives, the possibility of drafting a new Constitution creates uncertainty, fear and aversion. In their positions, one can verify the complexity of their bases, marked by rational cognitive evaluations and irrational feelings, such as, on the one hand, their institutional confidence, while, on the other hand, the dread that the creation of a new political order generates. This fear increases when the citizens are the ones who can intervene in the constituent process, in the absence of politicians who can neutralize the destruction of principles to which this group adheres, such as fundamental rights over social rights.

In short, this article constitutes a fundamental basis for understanding the trajectory of the business elites until establishing their opinion after the social outbreak. Undoubtedly, the perspectives of some businessmen may be modified as a consequence of a circumstantial event of such a magnitude as a social outbreak and the democratic processes that followed, such as the Agreement for Social Peace and the New Constitution and the National Referendum for a New Constitution, not to mention the development of the constitutional process in Chile, which is going to continue causing judgments within the big businessmen.

\section{ACKNOWLEDGEMENT}

Translated \& edited by American Publishing Services (https://americanpublishingservices.com/).

\section{ENDNOTE}

1. The districts of Vitacura, Las Condes, Lo Barnechea and Providencia are the districts with the highest revenues in the country according to the Observatorio del Gasto Fiscal en Chile. See www.observatoriofiscal.cl. The same is true for the highest levels of education, which are also found in these communes according to the latest 2017 Census. 


\section{REFERENCES}

Acemoglu, D., \& Robinson, J. (2012). Por qué fracasan los países: orígenes del poder, la prosperidady la pobreza. Barcelona: Deusto.

Arriagada, G. (2004). Los empresarios y la política. Santiago: Lom.

Atria, F. (2014). La Constitución tramposa. Santiago: Lom.

Atria, J., Amenábar, J., Sánchez, J., Castillo, J., \& Cociña, M. (2017). Investigando a la élite económica: Lecciones y desafíos a partir del caso de Chile. CUHSO-Cultura-Hombre-Sociedad, 27(2), 536.

Avendaño, O., \& Escudero, M. (2016). Elitismo y poder gremial en la Sociedad Nacional de Agricultura (SNA). Revista CS, (20), 37-74.

Avendaño, O., \& Osorio Rauld, A. (2021). Propuestas de cambio y debilidad institucional en Chile: De la revuelta social (2019) al inicio del funcionamiento de la Convención Constitucional. Revista de Ciencias Sociales Ambos Mundos, 2(in press).

Bardin, L. (1986). Análisis de contenido. Madrid: Akal.

Barómetro del Trabajo. (2020). Informe de participación electoral plebiscito 26 abril, enero. Fundación FIEL y CERC-MORI.

Bourdieu, P. (2012). Las estrategias de la reproducción social. Buenos Aires: Siglo XXI editores.

Campero, G. (1984). Los gremios empresariales en el período 1970-1983: Comportamiento sociopolítico y orientaciones ideológicas. Santiago: Instituto Latinoamericano de estudios transnacionales.

Cárdenas, J. (2016). Enredando a las élites empresariales en América Latina: Análisis de redes de Interlocking Directorates y propiedad en México, Chile, Perú y Brasil. América Latina Hoy, (73), $15-44$.

Centro de Estudios Públicos. (2017). Informe encuesta CEP 2016: ¿Malestar en Chile? Santiago: CEP. Cordero, G. (2015). La solución no es constitucional. In C. Fuentes \& A. Joignant (Eds.), La solución constitucional: Plebiscitos, asambleas, congresos, sorteos y mecanismos híbridos (pp. 83-96). Santiago: Catalonia.

Correa, S. (2005). Con las riendas del poder: La derecha chilena en el siglo XX. Santiago: Sudamericana. Criteria. (2020). Agenda ciudadana Criteria febrero 2020.

Dahse, F. (1979). El mapa de la extrema riqueza: Los grupos económicos y el proceso de concentración de capitales. Santiago: Aconcagua.

Desoc-Coes. (2019, October). Encuesta Termómetro Social. Santiago.

Elster, J. (1995). Forces and Mechanisms of the Constitution-Making Process. Duke Law Journal, (45), 364-396.

Emol. (2016, April 15). Andrónico Luksic señala a accionistas de Quiñenco: "Reformas generan incertidumbre y desconfianza". Retrieved from https://www.emol.com/noticias/Economia/2016/04/15/798135/Andronico-Luksic-senala-aaccionistas-de-Quinenco-Reformas-generan-incertidumbre-y-desconfianza.html

Escudero, M.C. (2021). Expectativas ciudadanas frente a una asamblea constituyente: La experiencia chilena. Revista de Ciencias Sociales Ambos Mundos, 2(in press).

Fazio, H. (2005). Mapa de la extrema riqueza al año 2005. Santiago: Lom.

Fuentes, C. (2012). El Pacto: Poder, Constitución y prácticas políticas en Chile (1990-2010). Santiago: UDP ediciones.

Fuentes, C., \& Joignant, A. (2015). La solución constitucional: Rutas de salida del antiguo orden y estrategias de entrada a una Nueva Constitución. In C. Fuentes \& A. Joignant (Eds.), La solución constitucional: Plebiscitos, asambleas, congresos, sorteos y mecanismos hibridos. Santiago: Catalonia.

García García, J. (2014). Minimalismo e incrementalismo constitucional. Revista Chilena de Derecho, 41(1), 267-302.

Garretón, M.A. (2015). Las ciencias sociales en la trama de Chile y América Latina. Estudios sobre transformaciones sociopolíticas y movimiento social. Santiago: LOM. 
Huneeus, C. (2014). La democracia semisoberana: Chile después de Pinochet. Santiago: Taurus.

Krippendorff, K. (1990). Metodología de análisis de contenido: Teoría y práctica. Barcelona: Paidós Comunicación.

La Tercera. (2015, April 30). Preocupación en gremios empresariales por anuncio de proceso constituyente. Retrieved from https://www.latercera.com/pulso/preocupacion-en-gremiosempresariales-por-anuncio-de-proceso-constituyente/

La Tercera. (2015, October 14). Empresarios: Reforma constitucional extenderá la incertidumbre. Retrieved from https://www.latercera.com/noticia/empresarios-reforma-constitucional-extenderala-incertidumbre/

La Tercera. (2015a, April 29). Presidente reelecto de la Sofofa manifiesta preocupación por "proceso constituyente" anunciado por Bachelet. Retrieved from https://www.latercera.com/pulso/vonmuhlenbrock-y-proceso-constituyente-ojala-que-esos-brotes-verdes-no-se-quemen-con-estospalitos-que-estamos-echando-al-fuego/

La Tercera. (2015b, April 29). Presidente de la CPC advierte que reforma constitucional podría afectar la inversión. Retrieved from https://www.latercera.com/noticia/presidente-de-la-cpc-advierte-quereforma-constitucional-podria-afectar-la-inversion/

La Tercera. (2020, January 28). Bernardo Larraín Matte, presidente de Sofofa: "Inicialmente estoy por el apruebo" a la nueva Constitución. Retrieved from https://www.latercera.com/pulso/noticia/bernardo-larrain-matte-presidente-de-sofofainicialmente-estoy-por-el-apruebo-a-la-nueva-constitucion/989674/

Lagos, R. (1960). La concentración del poder económico. Santiago: Editorial del Pacífico.

Larraín, S. (2006). El agua en Chile: Entre los derechos humanos y las reglas del mercado. Polis, Revista de la Universidad Bolivariana, 5(14).

Luna, J.P. (2016). Chile's crisis of Representation. Journal of Democracy, 27(3), 129-138.

Luna, J.P. (2017). En vez del optimismo. Crisis de representación politica en el Chile actual. CiperCatalonia.

Montero, C. (1997). La revolución empresarial chilena. Santiago: CIEPLAN.

Morán, M. (1997). Elites y cultura política en la España democrática. In P. del Castillo \& I. Crespo (Eds.), Cultura política, Valencia: Tirant lo blanch (pp. 185-222).

Navarro, P., \& Díaz, C. (1994). Análisis de contenido. In J. Delgado \& J. Gutíerrez (Eds.), Métodos y técnicas cualitativas de investigación en ciencias sociales (pp. 177-224). Madrid: Síntesis.

Negretto, G. (2015). Los procesos constituyentes en América Latina. Una visión comparada. Revista Argentina de Teoría Jurídica, 16, 2-23.

Osorio Rauld, A. (2019a). La cultura política de la élite empresarial chilena. Un análisis comparado de los dirigentes gremiales de la SNA y la SOFOFA (2018-2019) [Tesis doctoral, Universidad Complutense de Madrid]. Retrieved from https://eprints.ucm.es/id/eprint/59130/

Osorio Rauld, A. (2019b) ¡Que se vayan todos, que no quede uno solo! La crisis institucional en Chile: Factores contributivos del socavamiento de las bases culturales de la democracia (1990-2019). Revista de Investigaciones Políticas y Sociológicas, 18(2), 73-94. https://doi.org/10.15304/rips.18.2.6375

Osorio Rauld, A. (2019c). Las actitudes políticas de la élite empresarial chilena hacia la democracia en un contexto de una crisis. Política. Revista de Ciencia Política, 57(2), 7-27. Retrieved from https://revistapolitica.uchile.cl/index.php/RP/article/view/61554/67667

Osorio Rauld, A., \& Reig Cruañes, J. (2020). It's Always Been Business First: Breve análisis del discurso de las organizaciones empresariales españolas y chilenas ante las políticas para frenar el impacto del COVID-19. Ecuador Debate, (110), 95-112.

PNUD. (2015a). Opinión ciudadana y cambio constitucional: Análisis desde la opinión pública núm. 1. Santiago: Programa de Naciones Unidas para el Desarrollo.

PNUD. (2015b). Los tiempos de la politización. Santiago: Programa de Naciones Unidas para el Desarrollo.

182 Journal of Applied Business and Economics Vol. 23(6) 2021 
Putnam, R. (1973). The Beliefs of Politicians: Ideology, Conflicts and Democracy in Britain and Italy. New Haven C.T.: Yale University Press.

Rojas, G. (2013). Asamblea constituyente: ¿golpe de Estado? Una evaluación política y jurídica. Derecho Público Iberoamericano, (2), 289-299.

Rojas, J. (2012). La sociedad bloqueada: Movimiento estudiantil, desigualdad y despertar de la sociedad chilena. Concepción: RIL editores.

Rozas, P., \& Marín, G. (1989). 1988: El mapa de la extrema riqueza 10 años después. Santiago: Chile América CESOC.

Salamanca, A., \& Martin-Crespo, C. (2007). El muestreo en la investigación cualitativa. Nure Investigación, (27), 1-4.

Schmitt, C. (1996). Teoría de la Constitución. Madrid: Alianza.

SERVEL. (2020, October 26). Último boletín informativo sobre resultados parciales del Plebiscito Nacional 2020. Retrieved from https://www.servel.cl/wpcontent/uploads/2020/10/7_Boletin_Parcial_Total_ultimo-1.pdf

Thomas, R. (1995). Interviewing Important People in Big Companies. In R. Hertz, \& J. Imber (Eds.), Studying Elites Using Qualitative Methods (pp. 3-17). London: Sage Publications, Inc.

Undurraga, T. (2013). Instrucción, Indulgencia, Justificación: Los circuitos culturales del capitalismo chileno. In J. Ossandón \& E. Tironi (Eds.), Adaptación. La empresa chilena después de Friedman (pp. 135-166). Santiago: Universidad Diego Portales.

Van de Wyngard, J. (2013). Los aportes fundamentales de la Constitución de 1980 al sistema jurídicopolítico y social chileno. Derecho Público Iberoamericano, (2), 277-288. 